Wojciech Malchrzak, Weronika Rymer, Małgorzata Inglot

\title{
IMPORTED MALARIA CAUSED BY PLASMODIUM FALCIPARUM - CASE REPORT
}

\section{ZAWLECZONA MALARIA WYWOŁANA PRZEZ PLASMODIUM FALCIPARUM - OPIS PRZYPADKU}

\author{
Wrocław Medical University Students' Scientific Circle of Infectious Diseases, \\ Liver Diseases and Acquired Immune Deficiencies, \\ Wrocław Medical University Department and Clinic of Infectious Diseases, \\ Liver Diseases and Acquired Immune Deficiencies \\ Uniwersytet Medyczny im. Piastów Śląskich we Wrocławiu, Studenckie Koło Naukowe Chorób Zakaźnych, \\ Chorób Wątroby i Nabytych Niedoborów Odpornościowych \\ Uniwersytet Medyczny im. Piastów Śląskich we Wrocławiu, Katedra i Klinika Chorób Zakaźnych, Chorób \\ Wątroby i Nabytych Niedoborów Odpornościowych
}

\begin{abstract}
INTRODUCTION. Malaria is caused by the Plasmodium spp. which are spread through Anopheles mosquitoes. Disease is not endemic in Poland currently but can be brought from other countries, mostly from Africa and Asia. The main sign of the disease is fever with shivers repeated periodically. There is highly effective chemoprophylaxis available and treatment, which should be given quickly.

CASE REPORT. A 35-year-old man have worked monthly in Nigeria since two years. He was using Malarone chemoprophylaxis, but contrary to recommendations. Patient presented to a hospital after four days of having fever in a medium-serious state. He reported three similar incidents in the past. Physical examination revealed hepatomegaly, depressive state, oliguria and diarrhoea. Lab tests showed DIC with thrombocytopenia, renal injury, liver injury, hypoalbuminemia. ECG indicated myocardial ischemia. Malaria Rapid Test and blood smear confirmed Plasmodium falciparum infection with 9,9\% parasitemia. When antimalarial treatment was given, patient condition improved, but after three days in hospital he got pneumonia as a complication of malaria antibiotic admission was committed. Moreover, quinine caused temporary deafness and serological tests revealed chronic HBV infection. After 23-days of hospitalisation the patient was discharged in a good condition. A month later patient went to follow-up and only mild anaemia was shown.

CONCLUSIONS. This case shown that even such severe disease like malaria can be cured well without serious complications if patient will be diagnosed quickly. Moreover patient's experience and respecting symptoms improve prognosis. There also should be stronger emphasis on the role of chemoprophylaxis - patient did not use it properly, so it did not have to prevent development of malaria.
\end{abstract}

Key words: malaria, Plasmodium falciparum, chemoprophylaxis

\section{STRESZCZENIE}

WSTĘP. Malarię wywołują zarodźce z rodzaju Plasmodium, które są przenoszone przez komary widliszki. Choroba ta nie jest obecnie endemiczna w Polsce, ale może zostać zawleczona z innych krajów, najczęściej z Afryki i Azji. Głównymi objawami choroby jest gorączka i dreszcze, które powtarzają się okresowo. Istnieje wysoce skuteczna chemioprofilaktyka oraz leczenie, które najlepiej wdrożyć jak najszybciej.

OPIS PRZYPADKU. 35-letni mężczyzna pracował w Nigerii w systemie miesięcznym od dwóch lat. Używał profilaktycznie Malarone, jednak niezgodnie z zaleceniami. Pacjent zgłosił się do szpitala po czterech dniach z powodu gorączki w stanie średnio-ciężkim. Podawał w przeszłości trzy podobne incydenty. Badanie fizykalne ujawniło hepatomegalię, stan depresyjny, skąpomocz i biegunkę. Badania laboratoryjne wykazały zespół

(c) National Institute of Public Health - National Institute of Hygiene / Narodowy Instytut Zdrowia Publicznego - Państwowy Zakład Higieny 
rozsianego wykrzepiania wewnątrznaczyniowego z trombocytopenią, uszkodzenie nerek, uszkodzenie wątroby i hipoalbuminemię. Szybki test na malarię oraz rozmaz krwi potwierdziły infekcję Plasmodium falciparum z parazytemią $9,9 \%$. Po wdrożeniu leczenia przeciwmalarycznego stan pacjenta uległ poprawie, ale po trzech dniach wystąpiło zapalenie płuc jako powikłanie malarii - została włączona antybiotykoterapia. Ponadto podanie chininy spowodowało przejściowe uszkodzenie słuchu, a badania serologiczne ujawniły przebyte zakażenie HBV. Po 23 dniach hospitalizacji pacjent został wypisany w stanie ogólnym dobrym. Miesiąc później zgłosił się na kontrolę, w czasie której wykazano jedynie niewielką niedokrwistość.

WNIOSKI. Ten przypadek pokazuje, że nawet tak ciężka choroba jak malaria może być skutecznie wyleczona bez poważnych powikłań, jeżeli pacjent zostanie szybko zdiagnozowany. Ponadto doświadczenie pacjenta i nieignorowanie objawów polepsza rokowanie. Należy także silniej podkreślić rolę chemioprofilaktyki - pacjent nie stosował jej poprawnie, dlatego mogła ona nie chronić należycie przez malarią.

Słowa kluczowe: malaria, Plasmodium falciparum, chemioprofilaktyka

\section{INTRODUCTION}

Malaria is an infectious disease caused by Plasmodium parasites, mainly $P$. vivax, $P$. falciparum, $P$. ovalae, P. malariae and P. knowlesi. The mosquitoes of the genus Anopheles are the major vectors of infection, where the parasite undergoes a sexual stage of its life cycle (1). In 2016, there were 216 million cases of malaria resulting in approximately 429,000 deaths (2). In Poland since 1957, no case of domestic malaria has been reported and since 1963 Poland has been declared as malaria-free country, although there are still cases of imported malaria from other countries, especially Africa and Asia - there were 27 cases in 2017 (3). The main symptom of malaria is periodic fever, however the widespread use of antimalarial prophylaxis and antibiotics in recent years caused that non-typical course of fever occurs increasingly. Malaria often causes nonspecific symptoms (e.g. vomiting, diarrhoea, dyspnoea, muscle and joints pain). The course of disease caused by $P$. falciparum (tropical malaria) is usually different - the symptoms are more severe and, in addition, there are also signs of multiple organ failure such as hypoglycaemia, acidosis, jaundice, disseminated intravascular coagulation syndrome or acute respiratory distress syndrome $(4,5)$. There is no registered vaccine to prevent from malaria for travellers, therefore infection prophylaxis is limited to avoiding mosquitoes (proper clothes, repellents, mosquito nets) and to using specific chemoprophylaxis, which depends on the planned travel destination and patient's individual indications and contraindications. The chemoprophylaxis does not eliminate the risk of infection completely, but reduces it significantly, and if the disease develops, the course is milder and increases patient's chance to recover (6). The diagnosis of malaria is based on epidemiological history, signs, symptoms and laboratory tests (malaria rapid test which detects Plasmodium antigens such as specific lactate dehydrogenase, blood microscopy for a thin smear or thick drop, PCR test). After the diagnosis has been established, causative treatment should be

\section{WSTĘP}

Malaria to choroba zakaźna wywoływana przez zarodźce malarii z rodzaju Plasmodium, głównie $P$. vivax, $P$. falciparum, $P$. ovalae, $P$. malariae i $P$. knowlesi. Wektorem zarażenia jest komar, najczęściej widliszek (Anopheles spp.), w którym to pasożyt przechodzi płciową fazę swojego cyklu rozwojowego (1). W 2016 r. odnotowano ok. $216 \mathrm{mln}$ przypadków malarii, z czego ok. 429 tys. zakończyło się zgonem (2). W Polsce od 1957 r. nie odnotowano przypadku transmisji malarii rodzimej, a od 1963 r. uznano Polskę za kraj wolny od malarii. Mimo to ciągle występują przypadki zawleczone z innych krajów, najczęściej z Afryki i Azji - w 2017 r. odnotowano 27 przypadków (3). Głównym objawem malarii jest gorączka, która powtarza się w określonych odstępach czasu, chociaż w ostatnich latach powszechne korzystanie z profilaktyki przeciwmalarycznej oraz antybiotykoterapii sprawiły, że coraz częściej nie obserwuje się typowego, periodycznego przebiegu gorączki. Malaria wywołuje nierzadko objawy niespecyficzne jak np. wymioty, biegunki, duszność czy ból mięśni i stawów. Zwykle inaczej przebiega choroba wywołana przez P. falciparum (malaria tropikalna) objawy są znacznie bardziej nasilone, a do typowych objawów malarii dołączają się objawy niewydolności wielonarządowej w postaci między innymi hipoglikemii, kwasicy, żółtaczki, zespołu rozsianego wykrzepiania wewnątrznaczyniowego lub zespołu ostrej niewydolności oddechowej $(4,5)$. Nie ma zarejestrowanej szczepionki do stosowania $\mathrm{w}$ profilaktyce malarii u osób podróżujących, dlatego też profilaktyka zarażenia ogranicza się do unikania komarów (odpowiedni ubiór, repelenty, moskitiery) oraz do swoistej chemioprofilaktyki, której stosowanie uzależnione jest od planowanego kierunku wyjazdu, a także od indywidualnych wskazań i przeciwwskazań pacjenta. Chemioprofilaktyka nie eliminuje całkowicie ryzyka zarażenia, ale pozwala na jego znaczne obniżenie, a w przypadku rozwoju choroby sprawia, że przebieg 
started. Currently, it is based on several antimalarials with different mechanisms of action. Delay of treatment onset is an error that reduces patient's chance to recover (5).

\section{CASE REPORT}

A 35-year-old with irritable bowel syndrome with no significant medical history, has been admitted to the hospital with fever up to 40 degrees centigrade lasting for three days and being accompanied by shivers, headaches and muscle pain. The patient has reported three malaria incidents in the past. Before the admission, he has been taking doxycycline, in total 4 times per $100 \mathrm{mg}$. The patient has worked monthly in Nigeria for two years. He was using atovaquone with proguanil prophylactically, but he often discontinued after returning home.

On admission, the patient's condition was serious, temperature $37^{\circ} \mathrm{C}$, tachycardia $120 \mathrm{bpm}, \mathrm{BP} 100 / 70$, hepatosplenomegaly and depressed mood. Laboratory tests showed thrombocytopaenia, elevated aminotransferases, gamma-glutamyltransferase and alkaline phosphatase activity, elevated bilirubin, creatinine and C-reactive protein concentration and decreased albumin concentration (Tab. I). Coagulation system tests indicated DIC (Tab. II). ECG changes suggested myocardial ischaemia, but troponin concentration was normal. Renal USG was without abnormalities, but in the blood there was increased creatinine concentration and there were oliguria and haematuria.

Table I. Laboratory tests results at the first day Tabela I. Badania laboratoryjne w pierwszym dniu

\begin{tabular}{|c|c|c|c|}
\hline TEST & RESULT & UNITS & REFERENCE INTERVAL \\
\hline WBC & 5.36 & $10^{3} / \mu \mathrm{L}$ & $4.0-10.0$ \\
\hline RBC & 5.42 & $10^{6} / \mu \mathrm{L}$ & $4.5-6.0$ \\
\hline HGB & 16.2 & $\mathrm{~g} / \mathrm{dL}$ & $14.0-18.0$ \\
\hline HCT & 44.8 & $\%$ & $41.0-53.0$ \\
\hline MCV & 82.7 & $\mathrm{fL}$ & $80.0-98.0$ \\
\hline MCH & 29.9 & $\mathrm{pg}$ & $27.0-34.0$ \\
\hline MCHC & 36.2 & $\mathrm{~g} / \mathrm{dL}$ & $32.0-38.0$ \\
\hline PLT & $\mathbf{1 2} \downarrow$ & $10^{3} / \mu \mathrm{L}$ & $150-450$ \\
\hline ALT & $\mathbf{1 8 1} \uparrow$ & $\mathrm{IU} / \mathrm{L}$ & $0-40$ \\
\hline AST & $\mathbf{1 8 8} \uparrow$ & $\mathrm{IU} / \mathrm{L}$ & $0.2-1.2$ \\
\hline Bilirubin & $\mathbf{4 . 9} \uparrow$ & $\mathrm{mg} / \mathrm{dL}$ & $11-43$ \\
\hline GGTP & $\mathbf{1 7 5} \uparrow$ & $\mathrm{IU} / \mathrm{L}$ & $30-99$ \\
\hline ALP & $\mathbf{1 0 5} \uparrow$ & $\mathrm{IU} / \mathrm{L}$ & $0.61-1.24$ \\
\hline Creatinine & $\mathbf{1 . 3 3} \uparrow$ & $\mathrm{mg} / \mathrm{dL}$ & $<6$ \\
\hline CRP & $\mathbf{9 5 . 7} \uparrow$ & $\mathrm{mg} / \mathrm{L}$ & $3.5-5.0$ \\
\hline Albumins & $\mathbf{3 . 3} \downarrow$ & $\mathrm{g} / \mathrm{dL}$ & \\
\hline
\end{tabular}

jest lżejszy i pacjent ma większe szanse na wyzdrowienie (6). Diagnozę malarii stawia się na podstawie wywiadu epidemiologicznego, objawów oraz wyników badań laboratoryjnych (szybki test wykrywający antygeny zarodźca, takie jak np. specyficzna dehydrogenaza mleczanowa, badanie mikroskopowe krwi w formie cienkiego rozmazu lub grubej kropli, czy też badanie PCR). Po ustaleniu rozpoznania należy włączyć leczenie przyczynowe, które obecnie jest oparte na podawaniu kilku preparatów przeciwmalarycznych o różnym mechanizmie działania. Opóźnienie w rozpoczęciu leczenia jest błędem zmniejszającym szanse pacjenta na wyzdrowienie (5).

\section{OPIS PRZYPADKU}

35-letni mężczyzna z rozpoznanym zespołem jelita drażliwego, poza tym bez istotnej przeszłości chorobowej, zgłosił się do szpitala z powodu utrzymującej się od 3 dni gorączki do $40^{\circ} \mathrm{C}$ z towarzyszącymi dreszczami oraz bólami głowy i mięśni. Pacjent w wywiadzie podawał przebycie $\mathrm{w}$ przeszłości trzech incydentów malarii. Przed przyjęciem przyjmował doksycyklinę, łącznie 4 dawki po $100 \mathrm{mg}$. Pacjent od dwóch lat regularnie wyjeżdżał do pracy w Nigerii w systemie comiesięcznym, stosował profilaktycznie Malarone, ale często nie kontynuował przyjmowania leku po powrocie do domu. 
Table II. Coagulation system laboratory tests

Tabela II. Badania laboratoryjne układu krzepnięcia

\begin{tabular}{|c|c|c|c|}
\hline TEST & RESULT & UNITS & REFERENCE INTERVAL \\
\hline PLT & $\mathbf{1 2} \downarrow$ & $10^{3} / \mu \mathrm{L}$ & $150-450$ \\
\hline INR & $\mathbf{1 . 5 2} \uparrow$ & - & $0.8-1.3$ \\
\hline APTT & $\mathbf{4 9 . 3} \uparrow$ & $\mathrm{sec}$ & $25-41$ \\
\hline Fibrinogen & $\mathbf{3 . 6} \uparrow$ & $\mathrm{g} / \mathrm{L}$ & $1.8-3.5$ \\
\hline D-dimer & $>\mathbf{3 5 0 0 0} \uparrow$ & $\mathrm{ng} / \mathrm{mL}$ & $<500$ \\
\hline
\end{tabular}

During hospitalisation diarrhoea and jaundice also occurred. Malaria examinations (the rapid immunochromatographic test which detects antigens of Plasmodium and thick drop blood test) allowed diagnosing an infection. P. falciparum infection was diagnosed. The local laboratory determined parasitaemia at the level of approx. 3-5\% based on blood smear. Besides the diagnostics carried out at the local laboratory, malaria tests have been also run in the reference lab at the Department of Tropical and Parasitic Diseases in Poznań. The infection of Plasmodium falciparum with parasitaemia of $9,9 \%$ was confirmed with intraplasmatic hemozoin deposits in granulocytes, also HRP2 antigen was detected. The immunofluorescence test with $P$. falciparum antigen was positive in the ratio $1: 80$.

In the treatment doxycycline (administered intravenously) with mefloquine (administered orally) was used initially and after having established the Plasmodium species, quinine was added. Beside causative and symptomatic treatment, plasma, platelet concentrate and albumin was given to the patient.

On the fourth day of hospitalisation, pneumonia was diagnosed, amoxicillin with clavulanic acid and ciprofloxacin were used in the treatment. During hospitalisation, the patient occurred temporary deterioration of hearing, which was considered as an adverse effect of quinine - the otolaryngologist excluded other reasons. An abdomen ultrasound examination was performed four times, in which liver enlargement (up to $16 \mathrm{~cm}$ ) with steatosis was found. Diagnostic tests revealed serological features of chronic HBV infection.

Since the fifth day after admission, all malaria tests have been negative. Although body temperature rose on the fifteenth day, there was no malaria recurrence. Patient's state gradually improved during hospitalisation, bilirubin, creatinine, CRP concentrations and platelets count were normalised; after 23 days of hospitalisation patient was discharged in a good condition.

A month later, the patient was admitted to followup results of the treatment - only mild anaemia was present with no other significant complaints. The patient had planned the next trip to Nigeria, so he has been instructed about using antimalarial prophylaxis.
Przy przyjęciu pacjent byłw stanie średnio-ciężkim, temperatura $37^{\circ} \mathrm{C}$, tachykardia $120 / \mathrm{min}, \mathrm{BP} 100 / 70$, stwierdzono powiększenie wątroby i śledziony, zwracało uwagę obniżenie nastroju. Badania laboratoryjne wykazały małopłytkowość, podwyższoną aktywność aminotranferaz, GGTP i fosfatazy alkalicznej, podwyższone stężenie bilirubiny, kreatyniny i białka C-reaktywnego oraz obniżone stężenie albumin (Tab. I). Wyniki badań układu krzepnięcia wskazywały na DIC (Tab. II). W EKG obserwowano cechy przemawiające za niedokrwieniem mięśnia sercowego, ale stężenie troponiny mieściło się w normie. Obraz nerek w USG był prawidłowy, jednak we krwi występowało podwyższone stężenie kreatyniny oraz występował skąpomocz i krwinkomocz. W czasie hospitalizacji pojawiła się również biegunka i żółtaczka. Badania w kierunku malarii (szybki test immunochromatograficzny wykrywający antygeny Plasmodium oraz preparat grubej kropli) pozwoliły na rozpoznanie zarażenia, rozpoznano zarażenie $P$. falciparum. Przeprowadzający badanie diagnosta w lokalnym laboratorium określił parazytemię na podstawie rozmazu krwi na poziomie ok. 3-5\%. Oprócz diagnostyki prowadzonej w lokalnym laboratorium, badania w kierunku malarii były również wykonane $\mathrm{w}$ laboratorium referencyjnym w Klinice Chorób Tropikalnych i Pasożytniczych w Poznaniu. Potwierdzono zarażenie Plasmodium falciparum z parazytemią $9,9 \%$ oraz obecność wewnątrzplazmatycznych złogów hemozoiny w granulocytach obojętnochłonnych, a także wykryto antygen HRP-2. $\mathrm{W}$ teście immunofluorescencyjnym z antygenem $P$. falciparum uzyskano wynik dodatni przy mianie 1:80.

W leczeniu początkowo zastosowano doksycyklinę (podawaną dożylnie) z meflochiną (podawaną doustnie), po ustaleniu gatunku Plasmodium do leczenia dodano chininę. Poza leczeniem przyczynowym i objawowym u pacjenta suplementowano również osocze, koncentrat płytek krwi oraz albuminy.

W czwartym dniu hospitalizacji stwierdzono zapalenie płuc. W leczeniu zastosowano amoksycylinę z kwasem klawulanowym oraz ciprofloksacynę. U pacjenta w czasie hospitalizacji wystąpiło również przejściowe pogorszenie słuchu, które uznano za działanie niepożądane chininy; konsultujący otolaryngolog wykluczył inne przyczyny. 


\section{DISCUSSION}

Malignant malaria caused by $P$. falciparum is the most severe form of malaria and is accompanied by the highest deaths percentage compared to the other Plasmodium species' malaria. In this case there were numbers of factors that could potentially mitigate the course of the disease: chemoprophylaxis was used (even it was discontinued after returning home), the patient has probably survived three malaria incidents, and he started doxycycline treatment before admitting to the hospital. Diagnose of malaria was suspected already in the moment of admission; therefore, antiparasitic treatment was started immediately.

The patient presented signs and symptoms of severe malaria with multiple organ complications.

The intraplasmatic hemozoin deposits in granulocytes detected in the patient's blood were a result of haemoglobin's transformation by the parasite and it indicates severe malaria prognosis.

Parasitaemia in the patient was $9,9 \%$ which is extremely high value - exceeding $5 \%$ is life threatening.

Disseminated intravascular coagulation syndrome with intense thrombocytopaenia was a direct life threat, however platelets and plasma supplementation accompanied by causative treatment resulted in avoiding severe bleeding or embolic complications.

Despite severe course and multiple organ failure symptoms, this case would not fulfil the criteria for severe malaria set by WHO in 2015 (It would be on the verge of criteria; patient's parasitaemia was 9,9\% with a diagnostic criterion $>10 \%$ for $P$. falciparum) (7), nevertheless WHO's current guidelines from 2006 allowed to diagnose severe $P$. falciparum malaria (8).

The treatment scheme used initially (doxycycline with mefloquine) was not compatible with current WHO 2009 scheme, but the recommended artemisinin derivatives were not available, unlike to mefloquine. On the second day, quinine was obtained, and the patient has already been treated in accordance with WHO standards for seven days. In Poland, there are only a few medicines registered for malaria treatment (i.e. atovaquone with proguanil, doxycycline, chloroquine), that is why it is necessary to import drugs for treating patients in accordance with recommended scheme. In severe malaria, medications are administered parenterally, even if a patient can take them orally, because there may be absorption disorders in the gastrointestinal tract, and in our patient, DIC and diarrhoea indicated intestinal barrier damage.

This patient did not use the correct antimalarial chemoprophylaxis (he did not continue taking atovaquone with proguanil after he had come back) which hypothetically could disadvantageously affect the course of the disease, because medicines work during erythrocytic schizogony, so if a mosquito bite
W czasie hospitalizacji czterokrotnie wykonano badanie USG, w którym oprócz powiększenia wątroby (do $16 \mathrm{~cm})$, wykazano też cechy jej stłuszczenia. W toku prowadzonej diagnostyki stwierdzono serologiczne cechy przebytego zakażenia HBV.

Od piątego dnia po przyjęciu wszystkie testy w kierunku malarii były ujemne, pomimo ponownego wzrostu temperatury ciała, w piętnastym dniu nie stwierdzono wznowy malarii.

W trakcie hospitalizacji stan pacjenta ulegał stopniowej poprawie, normalizacji uległy stężenia bilirubiny, kreatyniny, CRP oraz liczba płytek krwi. Po 23 dniach hospitalizacji pacjent został wypisany do domu w stanie ogólnym dobrym.

Po upływie miesiąca pacjent został ponownie przyjęty do szpitala w celu kontroli wyników leczenia - obecna była jedynie niedokrwistość małego stopnia, poza tym nie stwierdzono żadnych innych znaczących dolegliwości. Pacjent planował ponowny wyjazd do Nigerii, dlatego został poinstruowany w zakresie stosowania profilaktyki przeciwmalarycznej.

\section{DYSKUSJA}

Malaria złośliwa wywoływana przez $P$. falciparum jest najcięższą postacią malarii i jest obarczona najwyższym odsetkiem zgonów w porównaniu do choroby wywoływanej przez inne gatunki Plasmodium. $\mathrm{W}$ omawianym przypadku u pacjenta wystąpił szereg czynników, które potencjalnie mogły złagodzić przebieg choroby: stosowana była chemioprofilaktyka (chociaż nie była kontynuowana po powrocie), pacjent w przeszłości prawdopodobnie przeżył trzy incydenty malarii, leczenie doksycykliną rozpoczął jeszcze przed przyjęciem do szpitala. Podejrzenie malarii zostało wysunięte już przy przyjęciu, dzięki czemu natychmiastowo rozpoczęto leczenie przeciwpasożytnicze.

Pacjent prezentował objawy ciężkiej malarii przebiegającej z powikłaniami narządowymi.

Wykryte u pacjenta wewnątrzplazmatyczne złogi hemozoiny $w$ granulocytach obojętnochłonnych to wynik przekształcania hemoglobiny przez pasożyta $i$ jest to zły prognostycznie marker ciężkiej malarii.

Parazytemia u pacjenta wynosiła $9,9 \%$, co jest wartością niezwykle wysoką, wartość przekraczająca $5 \%$ jest uznawana za zagrażającą życiu.

Bezpośrednie zagrożenie życia stanowił zespół rozsianego wykrzepiania wewnątrznaczyniowego $\mathrm{z}$ nasiloną trombocytopenią, jednak uzupełnienie płytek krwi oraz osocza wraz z leczeniem przyczynowym pozwoliły na uniknięcie poważnych powikłań krwotocznych lub zatorowych.

Mimo ciężkiego przebiegu i obecności objawów niewydolności wielu narządów, przytoczony przypadek nie spełniałby kryteriów ciężkiej malarii ustalonych 
occurs the last day of a trip, discontinuing the prophylaxis may result in too low medicine concentration to avoid the disease. Although high effectiveness of this kind of prophylaxis (9), still many travellers do not use it. They base on false premises or simply on ignorance (10).

Malaria still remains one of the most serious diseases worldwide, and despite the existence of chemoprophylaxis, effective treatment and intensive work on the vaccine, it is still the reason for many deaths all over the world. Moreover, it is known now that even after removing the parasite from the body, there may occur distant malaria complications, for instance from the skeletal system (11).

This case is neither unusual nor extremely rare for somebody who returns from tropical regions $(12,13)$. Similar situations also occurred in Poland - Salomon et al. described a case of a woman who, after having returned from Africa, had reported signs and symptoms similar to the patient described above (14). Our particular patient went to the hospital on the third day of fever, so he did not hesitate to long, but the main influence on the course had the fact, that he started the treatment (although not appropriate) at home. Studies show that the delay in starting antimalarial treatment, results in a higher risk of severe malaria $(15,16)$. Furthermore, it has been proved that the longer the period from the onset of symptoms to the diagnosis and the treatment is, the greater risk of death from malaria (17).

Among patients with severe P. falciparum malaria, in addition to respiratory failure and resulting acidosis, cases of acute kidney injury are often described. There is no evidence that geographical region, where the infection occurred, has an influence on the course $(18,19,20)$. Transient renal dysfunction was observed in our patient, but the criteria for diagnosing an acute kidney injury were not fulfilled.

Among the patient's complication, the most severe was the disseminated intravascular coagulation syndrome (DIC) with severe thrombocytopaenia. It occurs less frequently than the cerebral malaria (21), but if left untreated, it can quickly lead to death. Thrombocytopaenia is a very common sign of malaria $(22,23)$, it is also considered as a factor which differentiates malaria from other infections $(24,25)$.

Pneumonia, that occurred during hospitalisation, was most probably caused by disseminated intravascular coagulation syndrome in the course of malaria, which caused blood supply distress in the lungs and thus, increased bacterial infection susceptibility. Although the severe course, the presented patient recovered fully without any permanent complication.

According to the current WHO guidelines, chemoprophylaxis should be recommended for people who travel to malaria regions. In most cases, atovaquone przez WHO w roku 2015 (chociaż byłby na granicy rozpoznawalności, parazytemia u pacjenta na poziomie $9,9 \%$, przy kryterium rozpoznania $>10 \%$ dla $P$. falciparum) (7), niemniej ówcześnie obowiązujące wytyczne WHO z 2006 roku pozwoliły na rozpoznanie ciężkiej malarii w przebiegu zarażenia P. falciparum (8).

Zastosowany początkowo u pacjenta schemat leczenia (doksycyklina z meflochiną) nie był zgodny z obowiązującym wówczas, czyli 2009 r., schematem WHO, jednak zalecane pochodne artemizyny nie były wówczas dostępne w przeciwieństwie do meflochiny. Drugiego dnia udało się pozyskać chininę i wtedy pacjent był leczony już zgodnie ze standardami WHO przez 7 dni. W Polsce istnieje niewiele leków zarejestrowanych do leczenia malarii (atowakwon z proguanilem, doksycyklina, chlorochina), dlatego też, aby leczyć pacjenta w zalecanym schemacie, konieczne jest korzystanie z leków sprowadzanych na import docelowy. W ciężkiej malarii leki podaje się pozajelitowo, nawet jeżeli pacjent byłby w stanie przyjmować je doustnie, ponieważ mogą występować zaburzenia wchłaniania w przewodzie pokarmowym, a u tego pacjenta DIC oraz biegunka wskazywały na uszkodzenie bariery jelitowej.

Opisywany pacjent nie stosował prawidłowej chemioprofilaktyki przeciwmalarycznej (nie kontynuował przyjmowania Malarone po powrocie), co hipotetycznie mogło niekorzystnie wpłynąć na przebieg choroby, gdyż leki działają w czasie trwania schizogonii krwinkowej, więc jeżeli ukąszenie komara nastąpi np. w ostatnim dniu pobytu, to po przerwaniu profilaktyki po powrocie stężenie leku może być zbyt niskie do zwalczenia choroby. Pomimo wysokiej skuteczności tego rodzaju profilaktyki (9), ciągle wielu podróżujących z niej nie korzysta opierając się na fałszywych przesłankach, albo po prostu z niewiedzy (10).

Malaria ciągle pozostaje jedną $\mathrm{z}$ groźniejszych chorób świata i mimo istnienia chemioprofilaktyki, skutecznego leczenia oraz intensywnych prac nad szczepionką $\mathrm{w}$ dalszym ciągu jest przyczyną wielu zgonów na całym świecie. Co więcej, obecnie wiadomo, że nawet po usunięciu pasożyta $\mathrm{z}$ organizmu, mogą występować odległe powikłania malarii, np. ze strony układu kostnego (11).

Opisany przypadek nie jest wyjątkową, ani niezwykle rzadką sytuacją u osoby powracającej z tropiku (12), (13). Podobne sytuacje miały miejsce także w Polsce Salomon i wsp. opisywali przypadek kobiety, która po powrocie z Afryki zgłaszała objawy podobne do tych zgłaszanych przez omawianego pacjenta. (14). Omawiany pacjent zgłosił się do szpitala $\mathrm{w}$ trzeciej dobie trwania gorączki, więc nie zwlekał bardzo długo, jednak kluczowy wpływ na przebieg miało rozpoczęcie przez niego leczenia (choć niewłaściwego) już w domu. Badania wskazują, że opóźnienie we wdrożeniu leczenia przeciwmalarycznego skutkuje wyższym ryzykiem 
with proguanil will be the appropriate choice, especially in Poland, where this is one of the few registered medicines with this indication. Chloroquine, doxycycline, mefloquine and primaquine can also be used (7).

The basic treatment scheme for severe P. falciparum malaria treatment starts with the parenteral administration of artesunate, and after at least 24 hours, if a patient is able to take oral medicines, it is needed to continue with the ACT (Artemisinin-based Combination Therapy) for three days - artesunate with amodiaquine, artemether with lumefantrine or dihydroartemisinin with piperaquine. Mefloquine should be avoided due to the increased risk of neuropsychiatric complications. If ACT is not available, artesunate with clindamycin, artesunate with doxycycline, quinine with clindamycin or quinine with doxycycline can be used. The doxycycline therapy should be continued for seven days after having finished artesunate, artemether or quinine administration, but it should not be given to pregnant women and children - clindamycin is recommended for them instead (7).

\section{CONCLUSIONS}

Malaria should be eliminated in every patient returning from the endemic area who reports symptoms, even not directly indicating malaria, because immediate treatment significantly increases patient's chance to recover.

Bacterial pneumonia is one of the possible malignant malaria complications, most likely as a result of a blood supply distress caused by the disease.

It is necessary to educate travelling patients constantly in the area of malaria prevention, both by methods reducing the risk of mosquitoes bite, and correctly used chemoprophylaxis.

\section{REFERENCES}

1. Biernat B: Malaria i jej wektory w Polsce. W: Buczek A, Błaszak C, red. Stawonogi. Różnorodność form i oddziaływań; wydanie 1, Koliber, 2005, p. 281-287.

2. World Health Organization: World Malaria Report 2017, http://www.who.int/malaria/publications/ world-malaria-report-2017/en/

3. Narodowy Instytut Zdrowia Publicznego Państwowy Zakład Higieny - Zakład Epidemiologii: Choroby zakaźne i zatrucia w Polsce 2017 roku, podstawowe tablice robocze - wstępne dane, stan w dniu 1.03.2018 r., http://wwwold.pzh.gov.pl/ oldpage/epimeld/2017/Ch 2017 wstepne dane.pdf

4. Centers for Disease Control and Prevention: Treatment of Malaria (Guidelines For Clinicians), 2013, https://www.cdc.gov/malaria/diagnosis_treatment/ treatment.html ciężkiego przebiegu malarii $(15,16)$. Co więcej, udowodniono, że im dłuższy okres od wystąpienia objawów do postawienia diagnozy oraz do rozpoczęcia leczenia, tym większe ryzyko śmierci z powodu malarii (17).

Wśród pacjentów z ciężkim przebiegiem malarii wywołanej przez P. falciparum, oprócz niewydolności oddechowej i wynikającej z niej kwasicy, często opisuje się przypadki ostrego uszkodzenia nerek. Nie stwierdzono aby region geograficzny, w którym doszło do zarażenia miał wpływ na przebieg $(18,19,20)$. U omawianego pacjenta obserwowano przejściową dysfunkcję nerek, jednak nie było spełnionych kryteriów będących podstawą do rozpoznania ostrego uszkodzenia nerek.

Spośród powikłań, które wystąpiły u pacjenta, najpoważniejszym był zespół rozsianego wykrzepiania wewnątrznaczyniowego (DIC) z nasiloną małopłytkowością. Występuje on rzadziej niż malaria mózgowa (21), niemniej nieleczony w konsekwencji może szybko doprowadzić do śmierci pacjenta. Małopłytkowość jest bardzo częstym objawem malarii $(22,23)$, a także jest uznawana za jeden $\mathrm{z}$ czynników pozwalających odróżnienie malarii od innych infekcji $(24,25)$.

Zapalenie płuc, które wystąpiło w czasie hospitalizacji najprawdopodobniej było spowodowane zespołem rozsianego wykrzepiania wewnątrznaczyniowego w przebiegu malarii, co spowodowało zaburzenia ukrwienia w płucach, a tym samym zwiększyło podatność na zakażenie bakteryjne. Mimo ciężkiego przebiegu prezentowany pacjent powrócił $\mathrm{w}$ pełni do zdrowia bez trwałych powikłań.

Według obowiązujących wytycznych WHO osobom podróżującym $\mathrm{w}$ rejony występowania malarii należy zalecić chemioprofilaktykę. W większości przypadków odpowiednim wyborem będzie atowakwon z proguanilem, szczególnie w Polsce, gdzie jest jednym z niewielu dostępnych leków z takim wskazaniem. Można również stosować chlorochinę, doksycyklinę, meflochinę albo prymachinę (7).

Podstawowy schemat leczenia ciężkiej malarii wywołanej $P$. falciparum rozpoczyna się od pozajelitowego podania artesunatu, a po przynajmniej 24 godzinach, gdy pacjent może przyjmować leki doustnie, należy przez 3 dni kontynuować terapię ACT (Artemisinin-based Combination Therapy - terapia kombinowana na bazie artemizyny) - artesunat $\mathrm{z}$ amodiachiną, artemeter $z$ lumefantryną albo dihydroartemizyna $z$ piperachiną. Należy unikać meflochiny ze względu na zwiększone ryzyko powikłań neuropsychiatrycznych. W przypadku braku dostępności ACT dopuszczalne jest użycie artesunatu z klindamycyną, artesunat z doksycykliną, chininy z klindamycyną albo chininy z doksycykliną. Terapię doksycykliną należy kontynuować jeszcze 7 dni po zakończeniu cyklu artesunatu, artemeteru czy chininy, ale nie powinna być podawana ciężarnym i dzieciom w ich przypadku zalecana jest klindamycyna (7). 
5. Dziubek Z, red. Choroby zakaźne i pasożytnicze, Warszawa, PZWL, 2012, ISBN 978-83-200-45345, p. 502-513.

6. Kolifarhood, G, Raeisi A, Ranjbar M, et al.: Prophylactic efficacy of primaquine for preventing Plasmodium falciparum and Plasmodium vivax parasitaemia in travelers: A meta-analysis and systematic review; Travel Med Infect Dis, 2017;17:5-18.

7. World Health Organization: Guidelines for the treatment of malaria - Third Edition, 2015, p. 71$80,83 \mathrm{http} / / / \mathrm{www}$. who.int/malaria/publications/ atoz/9789241549127/en/

8. World Health Organization: Guidelines for the treatment of malaria, 2006, p. 41, $60 \mathrm{http} / /$ helid. digicollection.org/pdf/s13418e/s13418e.pdf

9. Nakato H, Vivancos R, Hunter PR: A systematic review and meta-analysis of the effectiveness and safety of atovaquone-proguanil (Malarone) for chemoprophylaxis against malaria. J Antimicrob Chemother, 2007;60:929-936.

10. Kuna A, Gajewski M, Stańczak J: Ocena znajomości i stosowania metod zapobiegania malarii wśród pacjentów kliniki chorób tropikalnych i pasożytniczych UCMMIT w Gdyni na podstawie badania ankietowego przeprowadzonego w latach 2012-2013. Przegl Epidemiol 2017;71(1):33-44.

11. Lee MSJ, Maruyama K, Fujita Y: Plasmodium products persist in the bone marrow and promote chronic bone loss; Sci Immunol. 2017;2;2(12).

12. Botella de Maglia J, Ceniceros Rozalén I, Oltra Chordá R: Multiple organ failure in Plasmodium falciparum malaria. Rev Clin Esp, 1995;195(10):688-92.

13. Carter C, Mukonka PS: Malaria: diagnosis, treatment and management of a critically ill patient; $\mathrm{Br}$ J Nurs, 2017;26:13:762-767.

14. Salamon D, Garlicki A: Zachorowanie na zimnicę zawleczone do polski - opis przypadku; Przegl epidemiol 2009;63:317-319.

15. Nakayama K, Shimizu T: Reducing the Delay in Initiation of Treatment Improved Clinical Outcomes in Patients with Imported Malaria. Jpn. J. Infect. Dis., 2014;67:27-32.

16. Landier J, Parker DM, Thu AM, et al.: The role of early detection and treatment in malaria elimination; Malar J, 2016;15:363.

17. Lüthi B, Schlagenhauf P: Risk factors associated with malaria deaths in travellers: a literature review. Travel Med Infect Dis, 2015;13(1):48-60.

18. Kuna A, Sulima M, Wołyniec W, et al.: Ostra niewydolność nerek w przebiegu malarii po podróży do Gambii i Senegalu. Forum Nefrologiczne, 2014;7(3):174-178.

\section{WNIOSKI}

Malarię należy wykluczyć u każdego chorego powracającego z obszaru endemicznego, który zgłasza objawy, nawet takie, które nie wskazują bezpośrednio na malarię, ponieważ szybkie rozpoczęcie leczenia znacząco zwiększa szanse pacjenta na powrót do zdrowia.

Jednym z możliwych powikłań malarii złośliwej może być bakteryjne zapalenie płuc, najprawdopodobniej wtórnie do wywołanych chorobą zaburzeń ukrwienia.

Konieczne jest ciągłe edukowanie pacjentów podróżujących w zakresie profilaktyki malarii, zarówno za pomocą środków zmniejszających ryzyko ukłucia przez komara, jak i za pomocą prawidłowo stosowanej chemioprofilaktyki.

19. Falade-Nwulia OO, Dhaliwal G, Schreiber MP, et al.: A 36-Year-Old Haitian Man With Coma, Acute Kidney Injury, Lactic Acidosis, and Respiratory Failure. Chest. 2012;142(3):798-801.

20. Boushab BM, Fall-Malick F, Savadogo M, et al.: Acute kidney injury in a shepherd with severe malaria: a case report. Int J Nephrol Renovasc Dis, 2016;9:249-251.

21. Sailo L, Pradhan D, Nongthombam R, et al.: Disseminated intravascular coagulation in malaria: A case report. Niger Med J, 2014;55(2):171-172.

22. Shaikh QH, Ahmad SM, Abbasi A: Thrombocytopenia in malaria: J Coll Physicians Surg Pak, 2009;19(11):708-10.

23. Gupta NK, Bansal SB, Jain UC, et al.: Study of thrombocytopenia in patients of malaria. Trop Parasitol, 2013;3(1):58-61.

24. Patel U, Gandhi G, Friedman S, et al.: Thrombocytopenia in malaria. J Natl Med Assoc, 2004;96(9):1212-1214.

25. Khan SJ, Abbass Y, Marwat MA: Thrombocytopenia as an Indicator of Malaria in Adult Population. Malaria Research and Treatment, 2012;2012:405981.

\section{Received: 17.07.2018}

Accepted for publication: 5.09.2018

Otrzymano: 17.07.2018 r.

Zaakceptowano do publikacji: 5.09.2018 r.

\section{Address for correspondence:}

Adres do korespondencji:

Małgorzata Inglot

Department and Clinic of Infectious Diseases,

Liver Diseases and Acquired Immune Deficiencies,

Wroclaw Medical University.

ul. Koszarowa 5, 51-149 Wrocław 